\title{
Maternal and foetal outcome of pregnancy in women with connective tissue diseases
}

\author{
Katarzyna Klimaszyk \\ Department of Reproduction, Department of \\ Obstetrics, Gynecology, and Gynecologic Oncology, \\ Poznan University of Medical Sciences, Poland \\ (D) https://orcid.org/0000-0002-9505-6140 \\ Corresponding author: kedjaworska@gmail.com

\section{Ewa Wender-Ożegowska} \\ Division of Reproduction, Department of Obstetrics, \\ Gynecology, and Gynecologic Oncology, Poznan \\ University of Medical Sciences, Poland \\ (iD) https://orcid.org/0000-0002-5492-8651

\section{Małgorzata Kędzia} \\ Division of Reproduction, Department of Obstetrics, \\ Gynecology, and Gynecologic Oncology, Poznan \\ University of Medical Sciences, Poland \\ https://orcid.org/0000-0002-8115-2019
}

DOI: https://doi.org/10.20883/medical.e525

Keywords: systemic connective tissue diseases, perinatal outcomes, pregnancy complications

Published: 2021-09-28

\begin{abstract}
How to Cite: Klimaszyk K, Wender-Ożegowska E, Kędzia M. Maternal and foetal outcome of pregnancy in women with connective tissue diseases. Journal of Medical Science. 2021 Sep. 28;90(3):e525. doi:10.20883/medical.e525
\end{abstract}

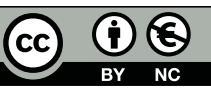

(c) 2021 by the author(s). This is an open access article distributed under the terms and conditions of the Creative Commons Attribution (CC BY-NC) licencse. Published by Poznan University of Medical Sciences

\section{ABSTRACT}

Introduction. The majority of patients diagnosed with systemic connective tissue diseases are women of childbearing age.

Aim. The analysis of obstetric results and exacerbation rates in the pregnancies involving systemic connective tissue diseases.

Material and Methods. We retrospectively reviewed perinatal outcomes of fourteen women with systemic connective tissue diseases hospitalised in the Department of Reproduction in the period between September 2019 and July 2021.

Results. Median duration of a pregnancy was 37 weeks. One pregnancy ended in a stillbirth in week 28. Of the 13 live births, preterm delivery occurred in 5 cases. Of the 13 live-birth neonates, preterm delivery occurred in five cases. The Caesarean section rate was $57.1 \%$ and vaginal delivery rate was $42.9 \%$. The mean birth weight of the live neonates was 2787 g (SD 892), and the median Apgar score in the 1st and the 3rd minute was 10.

In total, all 4 patients with the active disease at the time of conception and 1 who did not decide to undergo the recommended mitral valve surgery prior to pregnancy experienced symptoms indicating a disease flareup in the course of pregnancy. None of the patients who planned their pregnancy experienced an exacerbation of the disease.

Conclusions. All patients diagnosed with systemic connective tissue diseases should receive multidisciplinary care prior to conception, during pregnancy and in the postpartum period. Furthermore, they should be monitored by a team of specialists, due to the risk of a disease exacerbation and high rates of maternal and foetal complications resulting from the underlying condition.

\section{Introduction}

Systemic connective tissue diseases are a group of autoimmune diseases which occur significan- tly more frequently in women than in men [1]. The majority of the diagnosed patients are women of childbearing age. 
Their prevalence ranges from 2-4 per 10,000 people in terms of the most common rheumatoid arthritis, to 5-10 / 100,000 in scleroderma and systemic lupus. In fact, other systemic diseases are even less common [1].

Various large retrospective studies have proven an increased rate of adverse pregnancy outcomes, such as hypertensive disorders of pregnancy (gestational hypertension and pre-eclampsia), foetal growth restriction (FGR), premature delivery in patients with rheumatoid arthritis, as well as systemic lupus erythematosus [2-4]. However, the effects of other systemic connective tissue diseases have not been as extensively characterised.

The disease activity, extra-articular symptoms, and patient antibody status play a vital role in the risk stratification of these pregnancies. In fact, foetal atrioventricular block and the neonatal lupus syndrome constitute one of the most characteristic neonatal complications of pregnancy in women suffering from Sjögren's-syndrome-related antigen A (anti-SSA) and/or antigen B (anti-SSB) autoantibody-positive [5].

In the past, women with rheumatoid arthritis, systemic lupus erythematosus, systemic scleroderma, or the mixed connective tissue disease have been advised not to become pregnant due to the risk of a disease flare-up, adverse pregnancy outcomes, and the lack of evidence for safe treatment options during pregnancy. Nevertheless, with the increased knowledge regarding the management of patients with systemic connective tissue diseases, obstetric outcomes in these populations have also improved [6]. These advances highlight the importance of careful planning of the conception, multidisciplinary monitoring and treatment provided for women in this patient group.

\section{Aim}

The aim of the study was to analyse the obstetric results and exacerbation rates in the pregnancies of patients suffering from systemic connective tissue diseases.

\section{Materials and Methods}

We retrospectively reviewed the pregnancy outcomes of fourteen women with systemic connective tissue diseases at the Department of Reproduction for the period between September 2019 and July 2021.

The inclusion criteria of our retrospective observational study were the following: pregnant women diagnosed with diseases classified by the American Rheumatism Association as one of the systemic connective tissue diseases, who were under the care of the Department of Reproduction, Department of Obstetrics, Gynecology, and Gynecological Oncology, Poznan University of Medical Sciences, Poland. All study participants were followed up at regular intervals, with clinical and laboratory assessments during the entire term of the pregnancy. In patients with anti-SSA or anti-SSB antibody, an ultrasound assessment of foetal atrioventricular time intervals was performed.

The data analysed in this study were collected from the paper and electronic medical records of the study participants. Among these 14 women, 3 suffered from systemic lupus erythematosus, 3 from rheumatoid arthritis, 3 from the mixed connective tissue disease, while 2 had been diagnosed with overlap syndrome of rheumatoid arthritis and systemic lupus erythematosus, 1 suffered from the primary Sjögren's syndrome, 1 from

Table 1. Diagnoses of patients

\begin{tabular}{lc}
\multicolumn{1}{c}{ Diagnosis } & Number of patients \\
\hline Systemic lupus erythematosus & $3(21.4 \%)$ \\
\hline Rheumatoid arthritis & $3(21.4 \%)$ \\
\hline Mixed connective tissue disease & $3(21.4 \%)$ \\
\hline Overlap syndrome of rheumatoid arthritis and systemic lupus erythematosus & $2(14.3 \%)$ \\
\hline Primary Sjögren's syndrome & $1(7.1 \%)$ \\
\hline Systemic scleroderma & $1(7.1 \%)$ \\
\hline Dermatomyositis & $1(7.1 \%)$ \\
\hline
\end{tabular}


systemic scleroderma, and 1 presented with dermatomyositis (Table 1).

The mean age of the patients was 30 years (SD 5.9), whereas the mean age at the time of systemic connective tissue disease diagnosis was 23.6 years (SD 6.6). The average disease duration prior to the current pregnancy was 6.4 years (SD 4.0).

In the group of fourteen analysed pregnancies, one was a dichorionic diamniotic twin pregnancy, and thirteen were singletons. Eight pregnancies $(57.1 \%)$ in the study group were the first pregnancies for the patients, four (28.5\%) were the second, one was the third $(7.1 \%)$, and one was the fourth $(7.1 \%)$. Three patients $(21.4 \%)$ had a history of miscarriages prior to the current pregnancy (Table 2).

The following pregnancy outcomes were analysed: premature birth, stillbirth, number of women with preeclampsia, gestational week of delivery, Caesarean section rate, birth weight, Apgar score in the $1^{\text {st }}$ and the $3^{\text {rd }}$ minute, number of infants with FGR, and number of infants hospitalised in the Neonatal Intensive Care Unit (NICU).

In the study, the following definitions with regard to a pregnancy outcome were adopted:

, Spontaneous abortion - spontaneous loss of a foetus before the $22^{\text {nd }}$ week of gestation; premature birth (preterm) - live birth before the $37^{\text {th }}$ week of gestation. Stillbirth was defined as the death of a viable foetus (after the $22^{\text {nd }}$ week of gestation).

Preeclampsia - the evidence of proteinuria (> $300 \mathrm{mg} / 24$ hours) and hypertension, with or without oedema, in patients with normal blood pressure and no evidence of proteinuria prior to 20 weeks of gestation, or a significant increase in blood pressure and proteinuria, or new abnormalities in platelet count, or liver enzyme levels in the presence of pre-existing hypertension and proteinuria.

, FGR - according to the Delphi consensus: for early FGR (< 32 weeks), three solitary parameters (abdominal circumference $(A C)<3^{\text {rd }}$ centile, estimated foetal weight $(E F W)<3^{\text {rd }}$ centile and absent end-diastolic flow in the umbilical artery (UA)), and four contributory parameters (AC or EFW $<10^{\text {th }}$ centile combined with a pulsatility index $(\mathrm{PI})>95^{\text {th }}$ centile in either the UA or uterine artery). For late FGR ( $\geq 32$ weeks), two solitary parameters (AC or EFW $<3^{\text {rd }}$ centile) and four contributory parameters (EFW or $\mathrm{AC}<10^{\text {th }}$ centile, $\mathrm{AC}$ or EFW crossing centiles by $>$ two quartiles on the growth charts and cerebroplacental ratio $<5^{\text {th }}$ centile or UA-PI $>95^{\text {th }}$ centile).

Table 2. Characteristics of patients. The numbering of cases in Table 2 corresponds to the numbering of cases in Table 3

\begin{tabular}{|c|c|c|c|c|c|}
\hline $\begin{array}{l}\text { Case } \\
\text { no. }\end{array}$ & Diagnosis & $\begin{array}{l}\text { Obstetric history } \\
\text { (term births-preterm } \\
\text { births- abortions) }\end{array}$ & $\begin{array}{l}\text { Age at the time } \\
\text { of diagnosis } \\
\text { (years) }\end{array}$ & $\begin{array}{c}\text { Disease } \\
\text { duration } \\
\text { (years) }\end{array}$ & $\begin{array}{l}\text { Pregnancy } \\
\text { planning }\end{array}$ \\
\hline 1. & Rheumatoid arthritis & $(0-0-1)$ & 19 & 6 & No \\
\hline 2. & Systemic lupus erythematosus & $(0-0-0)$ & 15 & 4 & No \\
\hline 3. & $\begin{array}{l}\text { Overlap syndrome of rheumatoid arthritis and systemic } \\
\text { lupus erythematosus }\end{array}$ & $(0-0-0)$ & 31.5 & 0.5 & No \\
\hline 4. & Mixed connective tissue disease & $(0-1-0)$ & 39 & 5 & No \\
\hline 5. & Systemic lupus erythematosus & $(0-0-3)$ & 20 & 12 & No \\
\hline 6. & $\begin{array}{l}\text { Overlap syndrome of rheumatoid arthritis and systemic } \\
\text { lupus erythematosus }\end{array}$ & $(0-0-0)$ & 28 & 6 & Yes \\
\hline 7. & Rheumatoid arthritis & $(0-0-2)$ & 20 & 16 & Yes \\
\hline 8. & Systemic lupus erythematosus & $(0-0-0)$ & 24 & 7 & Yes \\
\hline 9. & Rheumatoid arthritis & $(0-0-0)$ & 18 & 6 & Yes \\
\hline 10. & Primary Sjögren's syndrome & $(0-0-0)$ & 31 & 3 & Yes \\
\hline 11. & Mixed connective tissue disease & $(0-0-0)$ & 23 & 6 & Yes \\
\hline 12. & Systemic scleroderma & $(0-0-0)$ & 26.5 & 0.5 & Yes \\
\hline 13. & Dermatomyositis & $(1-0-0)$ & 15 & 10 & Yes \\
\hline 14. & Mixed connective tissue disease & $(1-0-0)$ & 21 & 7 & Yes \\
\hline
\end{tabular}




\section{Results}

We identified fourteen women with systemic connective tissue diseases treated in the Department of Reproduction for the period between September 2019 and July 2021.

Ten pregnancies $(71.4 \%)$ occurred during the period of disease remission, and four of these pregnancies began while the patient was administered corticosteroid medications (prednisone or methylprednisolone).

One patient $(7.1 \%)$, with the remission of systemic lupus erythematosus 9 months prior to conception, dediced not to undergo the recommended mitral valve surgery before pregnancy.

Five of the pregnancies $(37.7 \%)$ were unplanned, and in three of these cases, drugs which are contraindicated in pregnancy were administered in the first trimester, including methotrexate in two cases and mycophenolate mofetil in one case.

\section{Effects of systemic connective}

tissue diseases on pregnancy

Median duration of pregnancy was 37 weeks. One pregnancy ended in the $28^{\text {th }}$ week of gestation with stillbirth, whereas a preterm delivery occurred in five cases $(38.5 \%)$ out of the 13 live birth pregnancies. In the $36^{\text {th }}$ week two of these pregnancies were associated with a premature rupture of membranes, whereas one twin pregnancy in the $32^{\text {nd }}$ week was linked to the inevitable labour. Moreover, in one pregnancy in the $32^{\text {nd }}$ week we observed symptoms of foetal distress in CTG and high bile acid levels as a result of intrahepatic cholestasis. Additionally, in yet another one in the $30^{\text {th }}$ week we found increasing respiratory insufficiency of the patient (Table 3). Nevertheless, two patients could not receive the recommended prophylactic dose of acetylsalicylic acid, one due to the acetylsalicylic acid induced asthma, and one due to thrombocytopenia. In the study, Caesarean section rate was $57.1 \%$, and the vaginal delivery rate was $42.9 \%$. Furthermore, three pregnancies $(21.4 \%)$ occurred in patients with lupus nephropathy, with two ending before the $37^{\text {th }}$ week. Antiphospholipid syndrome was diagnosed in one woman $(7.1 \%)$ with an obstetric history of three miscarriages, whereas preeclampsia occurred in one patient (7.1\%) (Table 4).
Effects of systemic connective tissue diseases on the neonatal outcome

The mean live neonatal birth weight was $2787 \mathrm{~g}$ (SD 892) and the median Apgar score in the $1^{\text {st }}$ and the $3^{\text {rd }}$ minute was 10 .

There was one stillbirth in the $28^{\text {th }}$ week of gestation in a patient with the mixed connective tissue disease, pregestational diabetes classes $\mathrm{RF} / \mathrm{H}$, multidrug resistant hypertension with renal, cardiovascular and proliferative retinopathy complications. This pregnancy was unplanned, began when the patient was taking methotrexate, and the disease exacerbation occurred in the $15^{\text {th }}$ week of gestation. The neonate's birth weight was 760 $\mathrm{g}$, below the $1^{\text {st }}$ percentile for the gestational age. In terms of other disorders, there were four cases (28.6\%) of FGR and no cases of neonatal lupus or congenital complete atrioventricular block. Four infants $(26.7 \%)$ were hospitalised in the neonatal intensive care unit (Table 3).

\section{Effects of pregnancy on systemic connective tissue diseases}

In total, all four patients with an active disease at the time of conception and one who would not undergo the recommended mitral valve surgery before pregnancy experienced symptoms indicating a disease flare-up during pregnancy. The patients presented with a lupus nephritis proteinuria level which increased from $0.5 \mathrm{~g} / 24 \mathrm{~h}$ before pregnancy to $2 \mathrm{~g} / 24 \mathrm{~h}$ in the first trimester. Five women experienced the exacerbation of articular symptoms, including two patients diagnosed with systemic lupus erythematosus, one with rheumatoid arthritis, one with the mixed connective tissue disease, and one with the overlap syndrome of rheumatoid arthritis and systemic lupus erythematosus. The patient suffering from rheumatoid arthritis needed an intra-articular injection of corticosteroids. The patient with systemic lupus erythematosus who did not decide to undergo the recommended mitral valve surgery before pregnancy developed respiratory insufficiency with pulmonary oedema, due to the exacerbation of mitral regurgitation in the complex defect of the mitral valve, whereas the pregnancy in the case of the patient with the mixed connective tissue disease pregnancy ended with stillbirth. 
Table 3. Detailed characteristics of pregnancy and foetal outcomes of women with connective tissue diseases. The numbering of cases in Table 2 corresponds to the numbering of cases in Table 3

\begin{tabular}{|c|c|c|c|c|c|c|c|}
\hline 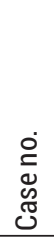 & 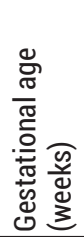 & 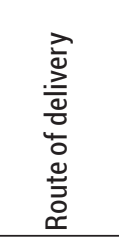 & 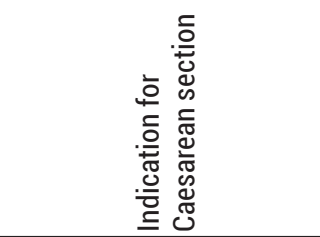 & 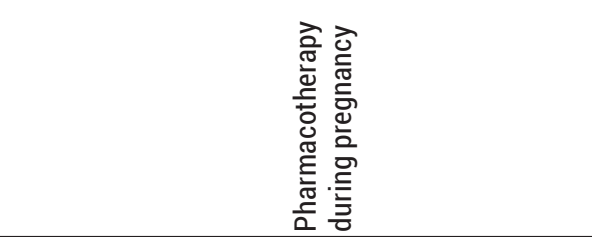 & 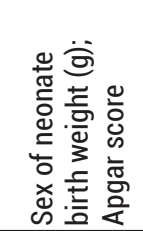 & 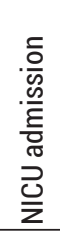 & 采 \\
\hline 1. & 37 & cs & $\begin{array}{l}\text { exacerbation of articular } \\
\text { symptoms }\end{array}$ & $\begin{array}{l}\text { - methotrexate continued until the 3rd week of } \\
\text { pregnancy } \\
\text { - methylprednisolone } \\
\text { - enoxaparin } \\
\text { - hydroxychloroquine } \\
\text { - acetylsalicylic acid }\end{array}$ & $\begin{array}{l}\mathrm{M} ; 2900 \mathrm{~g} ; \\
10,10\end{array}$ & No & No \\
\hline 2. & 38 & vag & - & $\begin{array}{l}\text { - mycophenolate mofetil continued until the 6th } \\
\text { week of pregnancy } \\
\text { - hydroxychloroquine } \\
\text { - methylprednisolone azathioprine } \\
\text { - levothyroxine } \\
\text { - acetylsalicylic acid }\end{array}$ & $\begin{array}{l}F ; 2200 \mathrm{~g} ; \\
10,10\end{array}$ & No & Yes \\
\hline 3. & 38 & CS & $\begin{array}{l}\text { exacerbation of articular } \\
\text { symptoms }\end{array}$ & $\begin{array}{l}\text { - methylprednisolone } \\
\text { - nadroparin } \\
\text { - methyldopa } \\
\text { - salbutamol } \\
\text { - fluticasone }\end{array}$ & $\begin{array}{l}\mathrm{M} ; 2980 \mathrm{~g} ; \\
10,10\end{array}$ & No & No \\
\hline 4. & 28 & $\begin{array}{c}\text { still- } \\
\text { birth-cs }\end{array}$ & $\begin{array}{l}\text { high blood pressure and } \\
\text { risk of uterus rupture dur- } \\
\text { ing labour induction due } \\
\text { to previous Caesarean } \\
\text { section }\end{array}$ & $\begin{array}{l}\text { - methotrexate continued till the 5th week of } \\
\text { pregnancy } \\
\text { - methylprednisolone insulin glargine } \\
\text { - insulin lispro } \\
\text { - methyldopa } \\
\text { - labetalol } \\
\text { - nitrendipine } \\
\text { - nadroparin } \\
\text { - acetylsalicylic acid levothyroxine }\end{array}$ & $\begin{array}{l}\mathrm{M} ; 760 \mathrm{~g} ; \\
0,0\end{array}$ & No & Yes \\
\hline 5. & 30 & CS & $\begin{array}{l}\text { increasing respiratory in- } \\
\text { sufficiency }\end{array}$ & $\begin{array}{l}\text { - hydroxychloroquine prednisone } \\
\text { - nadroparin } \\
\text { - acetylsalicylic acid verapamil } \\
\text { - levetiracetam } \\
\text { - oxcarbazepine }\end{array}$ & $\begin{array}{c}\mathrm{M} ; 1380 \mathrm{~g} ; \\
8,8\end{array}$ & Yes & No \\
\hline 6. & 37 & CS & lack of labour progress & $\begin{array}{l}\text { - hydroxychloroquine } \\
\text { - acetylsalicylic acid } \\
\text { - levothyroxine }\end{array}$ & $\begin{array}{c}\mathrm{F} ; 3220 \mathrm{~g} ; \\
10,10\end{array}$ & No & No \\
\hline 7. & 32 & CS & $\begin{array}{l}\text { symptoms of foetal dis- } \\
\text { tress in CTG and high bile } \\
\text { acid levels as a result of } \\
\text { intrahepatic cholestasis }\end{array}$ & $\begin{array}{l}\text { - hydroxychloroquine } \\
\text { - methyldopa } \\
\text { - verapamil } \\
\text { - acetylsalicylic acid } \\
\text { - enoxaparin } \\
\text { - ursodeoxycholic acid } \\
\text { - sulfasalazine }\end{array}$ & $\begin{array}{c}\mathrm{F} ; 1490 \mathrm{~g} ; \\
8,8,9\end{array}$ & No & Yes \\
\hline 8. & 39 & cs & $\begin{array}{l}\text { to lack of progress in la- } \\
\text { bour }\end{array}$ & $\begin{array}{l}\text { - methylprednisolone } \\
\text { - nadroparin } \\
\text { - acetylsalicylic acid }\end{array}$ & $\begin{array}{l}\mathrm{M} ; 3760 \mathrm{~g} ; \\
10,10\end{array}$ & No & No \\
\hline 9. & 32 & CS & $\begin{array}{l}\text { inevitable labour and } \\
\text { breech presentation of }\end{array}$ & - & $\begin{array}{l}F ; 1746 \\
g ; 7,7,8\end{array}$ & Yes & No \\
\hline & & & $\begin{array}{l}\text { a first foetus in a twin } \\
\text { pregnancy }\end{array}$ & & $\begin{array}{l}\mathrm{M} ; 1960 \mathrm{~g} ; \\
7,6,8\end{array}$ & Yes & No \\
\hline 10. & 36 & vag & - & $\begin{array}{l}\text { - hydroxychloroquine } \\
\text { - acetylsalicylic acid }\end{array}$ & $\begin{array}{l}\mathrm{F} ; 2840 \mathrm{~g} ; \\
10,10\end{array}$ & No & No \\
\hline 11. & 36 & vag & - & $\begin{array}{l}\text { - hydroxychloroquine } \\
\text { - methylprednisolone } \\
\text { - levothyroxine }\end{array}$ & $\begin{array}{l}\mathrm{M} ; 2065 \mathrm{~g} ; \\
10,10\end{array}$ & Yes & Yes \\
\hline 12. & 39 & vag & - & $\begin{array}{l}\text { - hydroxychloroquine } \\
\text { - acetylsalicylic acid insulin aspart }\end{array}$ & $\begin{array}{l}\mathrm{M} ; 3360 \mathrm{~g} ; \\
9,10\end{array}$ & No & No \\
\hline 13. & 38 & vag & - & $\begin{array}{l}\text { - methylprednisolone acetylsalicylic acid } \\
\text { - human insulin }\end{array}$ & $\begin{array}{c}\mathrm{F} ; 4220 \mathrm{~g} ; \\
10,10\end{array}$ & No & No \\
\hline 14. & 39 & vag & - & $\begin{array}{l}\text { - hydroxychloroquine } \\
\text { - enoxaparin } \\
\text { - acetylsalicylic acid }\end{array}$ & $\begin{array}{c}\text { M;3960; } \\
10,10\end{array}$ & No & No \\
\hline
\end{tabular}

cs - Caesarean section; vag - vaginal delivery; M - male; F - female; NICU - Neonatal Intensive Care Unit; FGR - foetal growth restriction 
Table 4 Perinatal outcomes of patients with systemic connective tissue diseases

\begin{tabular}{lc}
\multicolumn{1}{c}{ No. of pregnancies } & 14 \\
\hline Stillbirths & $1(7.1 \%)$ \\
\hline Premature deliveries (<37 week) & $5(38.5 \%)$ \\
\hline Term deliveries ( $\geq 37$ week) & $8(61.5 \%)$ \\
\hline Gestation duration (median) & 37 weeks $(\min 28 ; \max 39)$ \\
\hline Birth weight mean, (SD) & $2787 \mathrm{~g} \mathrm{(892)}$ \\
\hline Apgar score at the 1st minute (median) & 10 \\
\hline Apgar score at the 3rd minute (median) & 10 \\
\hline NICU admission & $4(26.7 \%)$ \\
\hline Foetal Growth Restriction & $4(28.6 \%)$ \\
\hline Preeclampsia & $1(7.1 \%)$ \\
\hline
\end{tabular}

\section{Discussion}

In our study, we described the courses of pregnancy and obstetric results in fourteen women with systemic connective tissue disease.

We found that all patients with active disease at the beginning of their pregnancy experienced the disease exacerbation during the pregnancy. The exacerbation involved articular symptoms, an increase in the proteinuria level, and pulmonary oedema, due to deterioration of the mitral valve function. As a result, four out of five patients gave birth by Caesarean section resulting from the exacerbation of the disease. One pregnancy ended in a vaginal delivery of the child with FGR. Moreover, two preterm deliveries occurred, one due to increasing respiratory insufficiency of the patient in the $30^{\text {th }}$ week of gestation, and one due to the intrauterine death of a $780 \mathrm{~g}$ foetus in the $28^{\text {th }}$ week of gestation.

Of the nine patients with systemic connective tissue disease who planned their pregnancy during a remission period, none experienced the exacerbation of their underlying disease during pregnancy. In this group, four women gave birth prematurely, stemming from the reasons not related to the underlying disease (two experienced PPROM in the $36^{\text {th }}$ week of gestation, one underwent Caesarean section due to inevitable preterm labour in the $32^{\text {nd }}$ week of gestation in a twin pregnancy, and another ended in the $32^{\text {nd }}$ week due to increasing cholestasis and pre-eclampsia.

Multiple previous studies have confirmed an increased risk for the mother, as well as foetal adverse pregnancy outcomes in women suffering from systemic connective tissue diseases. In fact, the authors of the study published in 2006 analysed the hospitalisations of 3,264 pregnant women with systemic lupus erythematosus, and 1,425 pregnant women with rheumatoid arthritis. The results of this analysis demonstrated a more than threefold increase in the risk of hypertension and IUGR compared to the general population [7]. Furthermore, Zucchi et al. retrospectively assessed the course of 100 pregnancies in 81 pregnant women with undifferentiated connective tissue disease between $2000-2018$. Obstetric complications occurred in 26 out of 89 pregnancies which ended in a live birth (29\%), including 1 case $(1 \%)$ of pre-eclampsia. In contrast, in other cases, a single pregnancy was affected by more than one complication. The stillbirth rate was $11 \%$. In 13 cases, there was the exacerbation of the underlying disease, with 3 cases which included the development of systemic lupus erythematosus with renal involvement [8]. In our study, 5 patients $(35.7 \%)$ out of 14 experienced the exacerbation of the underling disease, two of those cases included patents with lupus nephritis diagnoses.

The increased risk of an abnormal course of pregnancy in patients with systemic connective tissue diseases was not only due to the underlying disease, but also to the comorbidities or complications which occurred in the course of pregnancy. In 2019, Radin et al. assessed the obstetric outcomes of women with the mixed connective tissue disease in a multicentre study. Data for the 2000-2017 year period included 203 pregnancies in 94 women and were analysed retrospectively. The live birth rate was $71.9 \%$, the stillbirth rate was $8.9 \%$, and FGR rate $5.4 \%$ [9]. In the analysis of our group of patients, the rate of 
live births and FGR was significantly higher than in the cited study, and were, respectively, $92 \%$ and $28.6 \%$.

Nevertheless, in the last 50 years, the incidence of pregnancy morbidity in women with systemic lupus erythematosus has significantly decreased from $40 \%$ to $<15 \%$ [10]. The main cause for this improvement is associated with the pre-conception counselling, including the advice to choose a period of the disease quiescence for conception. Furthermore, the identification of the high risk factors related to pregnancy complications (a history of lupus nephritis, the presence of SSA and/or SSB antibodies and the coexistence of antiphospholipid syndrome), followed by appropriate monitoring of those patients is also essential.

The European League Against Rheumatism in 2017 published the first recommendations related to the management of pregnant women with systemic lupus erythematosus and/or antiphospholipid syndrome [10]. In fact, the coexistence of antiphospholipid syndrome is a very important risk factor of adverse obstetric outcomes in patients with systemic lupus erythematosus.

The risk of obstetric failures includes intrauterine foetal death, pre-eclampsia, placental insufficiency, and foetal growth restriction [11-14]. The current recommendations regarding pregnancy planning in this population suggest conception in a period when the disease symptoms have been reduced for at least six months. Additionally, the recommended pharmacotherapy during pregnancy involves a prophylactic dose of low-molecular-weight heparin and acetylsalicylic acid [14]. The abovementioned therapy of antiphospholipid syndrome increases the live birth rate from $20 \%$ to $70 \%$, compared to the group with the untreated disease. [15] However, a completely successful, full-term pregnancy and delivery of a healthy child cannot be guaranteed.

In the group of patients analysed in our study, one woman was diagnosed with systemic lupus erythematosus and antiphospholipid syndrome. Her three previous pregnancies ended with miscarriage. During her fourth pregnancy, the one analysed in our study, nadroparin and acetylic acid were administered, and her pregnancy ended with a preterm Caesarean section delivery of a live, preterm neonate. Nevertheless, most patients with systemic lupus develop seconda- ry or steroid-induced cardiovascular complications. They are not the most common manifestations of systemic lupus, but the most dangerous ones, constituting the main cause of death in this patient group [16].

Another risk factor for an increased rate of pregnancy complications in patients diagnosed with systemic connective tissue disease is the coexistence of hypertension. Interestingly, arterial hypertension develops in approximately $70 \%$ of patients with systemic lupus erythematosus [17]. This is usually a consequence of chronic renal disease, due to lupus nephritis, or a result of chronic steroid therapy. In fact, every increase in the daily dose of steroids by $10 \mathrm{mg}$ elevates arterial blood pressure by $1.1 \mathrm{~mm} \mathrm{Hg}$ [17]. The recommended treatment in patients with lupus and arterial hypertension includes the lowest effective doses of steroids and intensive hypotensive therapy [17]. In fact, the coexistence of hypertension and systemic connective tissue disease was observed in four of our patients (28.6\%). Three of them were diagnosed with nephritis, while one patient developed preeclampsia.

Following atherosclerosis and pericarditis, mitral regurgitation is one of the most common cardiac complications in the lupus patients [16]. The prevalence of this disorder is approximately $28 \%$, and in patients with systemic lupus and concurrent antiphospholipid syndrome, mitral regurgitation is found significantly more often $(38 \%)$ than in the population of patients without antiphospholipid syndrome (12\%) [16]. Additionally, patients with a major mitral regurgitation are significantly more often at risk of stroke, peripheral embolism, the need of heart valve replacement and death, compared to patients with systemic lupus, but without a major defect ( $86 \%$ vs. $25 \%$, respectively; $p=0.003$ ) [18]. In fact, major mitral insufficiency is more often observed in patients with high levels of IgG anticardiolipin antibodies (50\% vs. $3 \%$ ) [14]. In our study, one of patients, with a complex defect of the mitral valve, was qualified for mitral valve surgery before pregnancy. However, she decided not to undergo this operation, which resulted in the development of respiratory insufficiency with pulmonary oedema due to the exacerbation of mitral regurgitation. This precipitated an urgent preterm Caesarean section delivery in the $30^{\text {th }}$ week of gestation. 
In conclusion, as our study demonstrated, the significance of pregnancy planning and appropriate pre-contraceptive treatment in patients with systemic connective tissue diseases should be emphasised. In our material, the live birth rate was $92 \%$. Nevertheless, it is worth bearing in mind that the most severe perinatal complications, including intrauterine death and urgent preterm Caesarean section delivery due to respiratory failure, were found in the group of patients insufficiently prepared for pregnancy. Therefore, these pregnant patients should be referred for treatment in the reference centres, so that the delivery time can be chosen in the case of sudden deterioration of their condition, providing a chance of survival for the neonate and the mother. In fact, none of the patients who planned the pregnancy experienced the exacerbation of the disease, which contributed to better obstetric outcomes.

\section{Acknowledgements}

\section{Conflict of interest statement}

The authors declare no conflict of interest.

\section{Funding sources}

There are no sources of funding to declare.

\section{References}

1. Gaubitz M. Epidemiology of connective tissue disorders. Rheumatology (Oxford). 2006 Oct;45 Suppl 3:iii3-4. doi: 10.1093/rheumatology/kel282. Erratum in: Rheumatology (Oxford). 2008 Feb;47(2):234-5. PMID: 16987829

2. Chakravarty, E. F., Nelson, L. \& Krishnan, E. Obstetric hospitalizations in the United States for women with systemic lupus erythematosus and rheumatoid arthritis. Arthritis Rheum. 54, 899-907 (2006).

3. Buyon, J. P. et al. Predictors of pregnancy outcomes in patients with lupus: a cohort study. Ann. Intern. Med.163, 153-163 (2015).

4. Arkema, E. V. et al. What to expect when expecting with systemic lupus erythematosus (SLE): a population-based study of maternal and fetal outcomes in SLE and pre-SLE. Arthritis Care Res. 68, 988-994 (2016).

5. Zuppa, A. A. et al. Neonatal lupus: follow-up in infants with anti-SSA/Ro antibodies and review of the literature. Autoimmun. Rev. 16, 427-432 (2017)

6. Clark CA, Spitzer KA, Laskin CA. Decrease in pregnancy loss rates in patients with systemic lupus erythematosus over a 40-year period. J Rheumatol [Internet]. 2005 Sep. [cited 2017 Dec 18];32(9):170912. Available from: http://www.ncbi.nlm.nih.gov/ pubmed/16142865
7. Chakravarty EF, Nelson L, Krishnan E. Obstetric hospitalizations in the United States for women with systemic lupus erythematosus and rheumatoid arthritis. Arthritis Rheum. 2006;54:899-907. doi: 10.1002/art. 21663

8. Dina Zucchi, Chiara Tani , Francesca Monacci et al. Pregnancy and undifferentiated connective tissue disease: outcome and risk of flare in 100 pregnancies. Rheumatology (Oxford). 2020 Jun 1;59(6):13351339. doi: 10.1093/rheumatology/kez440.

9. Massimo Radin et.al. Pregnancy outcomes in mixed connective tissue disease: a multicentre study. Rheumatology 2019 Nov 1;58(11):2000-2008. doi: 10.1093/rheumatology/kez141.

10. Andreoli L, Bertsias GK, Agmon-Levin N, et al. EULAR recommendations for women's health and the management of family planning, assisted reproduction, pregnancy and menopause in patients with systemic lupus erythematosus and/or antiphospholipid syndrome. Annals of the Rheumatic Diseases 2017;76:476-485.

11. Bouvier S, Cochery-Nouvellon E, Lavigne-Lissalde $\mathrm{G}$, et al. Comparative incidence of pregnancy outcomes in treated obstetric antiphospholipid syndrome: the NOH-APS observational study. Blood 2014;123:404-13. doi:10.1182/blood-201308-522623

12. Jeremic K, Stefanovic A, Dotlic J, et al. Neonatal outcome in pregnant patients with antiphospholipid syndrome. J Perinat Med 2015;43:761-8. doi:10.1515/ jpm-2014-0118

13. Cervera R, Piette JC, Font J, et al. Antiphospholipid syndrome: clinical and immunologic manifestations and patterns of disease expression in a cohort of 1,000 patients. Arthritis Rheum 2002;46:101927. doi:10.1002/art.10187

14. Alijotas-Reig J, Ferrer-Oliveras R, Ruffatti A, et al The European Registry on Obstetric Antiphospholipid Syndrome (EUROAPS): a survey of 247 consecutive cases. Autoimmun Rev 2015;14:387-95. doi:10.1016/j. autrev.2014.12.010

15. Mak A. et al. Combination of heparin and aspirin is superior to aspirin alone in enhancing live births in patients with recurrent pregnancy loss and positive anti-phospholipid antibodies: a meta-analysis of randomized controlled trials and meta-regression. Rheumatology 2010; 49,281-288

16. Chrzanowska A, Irzyk K, Dudzik-Niewiadomska I. et al Circulatory system in patients with systemic lupus erythematosus Folia Cardiologica 2016 ; 11 (2), 111118

17. Petri M., Lakatta C., Magder L.,Goldman D. Effect of prednisone and hydroxychloroquine on coronary artery disease risk factors in systemic lupus erythematosus: a longitudinal data analysis. Am. J. Med. 1994; 96: 254-259.

18. Perez-Villa F., Font J., Azqueta M. et al. Severe valvular regurgitation and antiphospholipid antibodies in systemic lupus erythematosus: a prospective, long-term, followup study. Arthritis Rheum. 2005; 53: $460-467$ 